\title{
Vergilius, Horatius és Ovidius magyarországi recepciója Palingenius Zodiacus vitae-jének magyar fordításaiban
}

\begin{abstract}
The Italian humanist Marcellus Palingenius Stellatus, the author of Zodiacus vitae, a popular teaching poem (philosophical poem, epic, "great epic") published in several editions and translations throughout Europe for centuries, is one of the mysterious figures in the history of European literature. His biography is largely uncertain, and is mainly derived from the work itself. this work is a moral and philosophical poem divided into twelve books according to the signs of the zodiac. The zodiac signs follow each other according to the ancient Roman calendar. To summarize the knowledge of man available in the early 16th century, Palingenius used the works of antique authors, especially the poems of Virgil, Horace and Ovid. His allusions, adaptations and transpositions, as well as their sources, are extremely diverse. After the first Venetian edition presumably dated 1531, new editions of the book appeared in succession, even though it was constantly on the list of forbidden books (Index librorum prohibitorum) from 1557 onwards. The impact history of the work has long been a separate research topic, but it has not been dealt with in Hungary so far. Translations of the national languages of the Zodiacus vitae have been and continue to be produced since the second half of the $16^{\text {th }}$ century. The first and still the only complete manuscript translation in Hungarian was made by József Elefánti Jáklin in 1771. The manuscript was not published, but several copies survived in Bratislava, Budapest, Eger and Pécs. There is no exact answer to the question of which Latin edition Jáklin translated as the catalogue of the his library is unknown. ${ }^{1}$
\end{abstract}

Marcellus Palingenius Stellatus itáliai humanista, a Zodiacus vitae ${ }^{2}$ címü, számos kiadást és fordítást megért, évszázadokon át Európa-szerte ked-

\footnotetext{
${ }^{1}$ A publikáció az MTA-SZTE Antikvitás és Reneszánsz: Források és Recepció Kutatócsoport (TK2016-126) támogatásával jelent meg.

${ }^{2}$ Kritikai kiadás: CHOMARAT (1996). A kiadást ZV rövidítéssel, római számos kötetjelzéssel és a verssorok számával hivatkozom. - A tanulmány előzményei: Palingenius Zodiacus vitae-je a magyarországi Album Amicorumokban címen az A\&R II-ben jelent meg;
} 
velt tanköltemény (filozofikus poéma, eposz, „nagyeposz”) szerzője az európai irodalom történetének rejtélyes alakjai közé tartozik. Életrajzi adatai jelentős részben bizonytalanok, ${ }^{3}$ ezek nagyrészt magából a müből származnak.

A Zodiacus vitae az állatöv jegyei szerint tizenkét könyvre tagolt erkölcstani, morálfilozófiai poéma. A jegyek az antik római naptárnak megfelelően követik egymást. A részben metafizikai-teológiai, részben tudományos szemléletü tanköltemény, epikus „világtükör” szerzője az emberi boldogság és a legfőbb jó (summum bonum) mibenlétét keresi. Foglalkozik - többek között - a valódi bölcsesség lépcsőfokaival, az élet optimális rendjével és természetfilozófiával. A boldogság lényegének keresését összeköti tudományos ismeretekkel és metafizikai spekulációkkal, miközben szatirikus hangot üt meg - elsősorban az egyházi képmutatást illetően. ${ }^{4}$ Egy mondatban összegezve, a mü lényegében a kereszténység neoplatonikus átértelmezése az antikvitás ismeretében, az üdvtörténet mellőzésével. ${ }^{5}$ A verses argumentum szerint az első, bevezető könyv (Aries) után a második könyv (Taurus) a gazdagság, a harmadik (Gemini) az élvezetek, a negyedik (Cancer) Vénusz, az ötödik (Leo) a boldogság, a hatodik (Virgo) a halál és a nemesség témáját tárgyalja. A hetedik könyvben (Libra) az istenek és a lélek, a nyolcadikban (Scorpio) a sors hatalmának, a kilencedikben (Sagittarius) az ördög és az emberi szokások megismerése, a tizedikben a bölcs ember (Capricornus), a tizenegyedikben (Aquarius) a természet, a tizenkettedikben (Pisces) a teremtett világ ősi alakjának kérdései állnak a középpontban.

Palingenius Zodiacus vitae-je a magyarországi könyvtárakban címen az A\&R III-ban jelent meg; Palingenius Zodiacus vitae-je a régi magyar irodalomban, Irodalomtörténeti Közlemények 122 (2018), 127-144; Palingenius Zodiacus vitae-jének magyarországi forditásai, A reformáció és a katolikus megújulás latin nyelvű irodalma, szerk. Békés Enikő, Kasza Péter, Kiss Farkas Gábor, Lázár István, Molnár Dávid, Budapest, MTA BTK ITI, 2019, 173-183.

3 PALUMBO (2007: 294-298) Életét feltételesen 1500-1551 közé datálják, a legváltozatosabb variációkban. Vö. CERL Thesaurus. A „Stellatus” névelem alapján születési helyét több lexikon Ferrara tartomány Stellata településére helyezi. Másutt születési helyeként Nápolyt valószínűsítik.

${ }^{4}$ KELLER (1974: 9-60); TELLE (2013: 503-508).

${ }^{5}$ KÜHLMANN (2016: 62-77). 
Palingenius a 16. század elején az emberről rendelkezésre álló tudás összegzése során folyamatosan és invenciózusan használta az antik szerzők müveit, elsősorban Vergilius, Horatius és Ovidius költeményeit. Allúziói, adaptációi és gondolatátvételei, valamint ezek forrásai rendkívül változatosak. A görög szerzőket Homérosz, Hésziodosz, Arisztotelész és Diogenész Laertiosz képviseli. A rómaiakat a már említetteken kívül Plautus, Terentius, Cicero, Catullus, Lucretius, Seneca és Petronius reprezentálja. Visszatérően utal az idősebb Plinius Naturalis historiájára. Az itáliai humanizmust a leggyakrabban Petrarca (Epistolae meretricae) és Boccaccio (Genealogia deorum gentilium libri) képviseli a források között. Kortársai közül Palingenius szívesen hivatkozik Erasmusra, elsősorban az Adagiára. A Zodiacus vitae-ben a felsorolt szerzők mellett viszonylag ritkák az ó- és újszövetségi utalások, melyek az esetek jelentős részében együtt vagy egymás közelében jelennek meg.

A mű első, feltételesen 1531-re datált velencei megjelenését követően egymás után láttak napvilágot újabb kiadásai, annak ellenére, hogy 1557től folyamatosan megtalálható volt a tiltott könyvek jegyzékén (Index librorum prohibitorum). ${ }^{6}$ A 16. század végéig mintegy harminc, 1832-ig összesen közel ötven kiadása jelent meg szerte Európában. A recepciót elősegítette, hogy rétegzetten, a legkülönfélébb szinteken, eltérő módon és formákban lehetett értelmezni a szöveget. A Zodiacus vitae gyorsan közkedveltté vált, elsősorban mint „tudáskompendium”. Egyházkritikai szemlélete és kiemelkedő nyelvi eleganciája miatt nagyon sokan idézték és használták évszázadokon át különféle kontextusokban, köztük olyan szerzők, mint Julius Caesar Scaliger és Giordano Bruno. Palingenius kortársa, Julius Caesar Scaliger a Poetices libri septem hatodik, Hypercriticus címü kötetében oldalakon át, részletesen foglalkozott vele. Véleménye szerint: „Palingenii poema totum Satyra est: sed sobria, non insana, non foeda." ${ }^{7}$ E sorok jelentős mértékben hozzájárultak a munka európai elterjedéséhez a poétikaoktatásban. A Zodiacus vitae-t a latin nyelv „mesteri” használata révén poétikairetorikai tankönyvként is használták; a 16. század második felétől különféle, módszeresen még számba nem vett, anonim Zodiacus-kivonatok sora

\footnotetext{
${ }^{6}$ De BujANDA (1990: 602, nr. 700; Index de 1557 Roma 00166; Index de 1558 Louvain 162; 275-292); 1764-ben: Index (1764: 165); 1862-ben: Index (1862: 331).

7 SCALIGER (1607: 731-734).
} 
készült Európa-szerte. A mü hatástörténete régóta külön kutatási téma, Magyarországon azonban eddig nem foglalkoztak vele.

Mindez arra ösztönzött, hogy megkíséreljem feltárni a mü magyarországi befogadás-történetének fő vonalait. ${ }^{8}$ A Zodiacus vitae-nek nem ismert magyarországi nyomtatott kiadása, de a különféle kiadásokból számos példány jutott el az egyházi, főnemesi, nemesi, egyetemi és polgári könyvtárakba. Beszerzése, birtoklása és használata a 16. század második felétől folyamatosnak tekinthető. A külföldet járt magyarországi diákok 17-18. századi album amicorumainak bejegyzései között számos Palingenius-idézet található. Az elsődleges recepció mellett megragadható a müben idézett antik költők, köztük Vergilius, Horatius és Ovidius másodlagos befogadás-története a fordításokba átszármazott antik reminiszcenciák révén. A továbbiakban először röviden bemutatom a Zodiacus vitae két magyar fordítását, majd kiválasztott példák segítségével megvizsgálom Vergilius, Horatius és Ovidius recepcióját a fordításokban.

\section{A magyar fordítások}

A 16. század második fele óta folyamatosan készültek és készülnek ma is nemzeti nyelvü Zodiacus vitae-fordítások. ${ }^{9}$ Ismereteim szerint a 18. század második fele előtt Magyarországon nem keletkezett olyan magyar, német vagy más nyelvü Palingenius-adaptáció, amely nem egy adott szövegkörnyezethez illeszkedő idézet-rész átültetése, hanem a mű teljes, vagy részleges fordítása. Ennek oka elsősorban az alfabetizált rétegek latin (tan)nyelvüségében kereshető: aki olvasta közülük a Zodiacus vitae-t, tudott latinul, és e nyelven olvasta, illetve e nyelv ismerete alapján értelmezte.

\footnotetext{
${ }^{8}$ A teljes dolgozat bemutatja a Zodiacus vitae előfordulását a történeti könyvtárakban, könyvjegyzékekben és könyvbeszerzésekben, a jelenkori könyvtári állományokban, vizsgálja a mű idézését az album amicorumokban és a régi magyar irodalomban, $\mathrm{s}$ részletesen foglalkozik magyarországi fordításaival.

9 Teljes terjedelmü német fordítások például: Johannes Spreng, Zodiacus Vitae, das ist Gürtel deß Lebens (1564, 1599), Franz Schisling, Thierkreis des Lebens (1785, 31788), Johann Joseph Pracht, Thierkreis des Lebens (I-IV, 1803-1815), Marcellus Aurelius Hug, Thierkreis des Lebens (1873). Fennmaradt az emlékezete Christoph Wirsung (1500-1571) tudományos igényü Zodiacus vitae-kommentárjának is. CHOMARAT (1996: annoté, Appendices, 506).
} 
A fennmaradt első, és mindmáig egyetlen teljes magyar nyelvü kéziratos fordítást Elefánti Jáklin József készítette 1771-ben. A kézirat megjelentetése elmaradt, ${ }^{10}$ ugyanakkor több másolata maradt fenn Pozsonyban, Budapesten, Egerben és Pécsett. ${ }^{11}$ A másolatok bizonyítják, hogy a fordítás meglévő igényt elégített ki. Biztos „életrajzi” adat mindössze annyi, hogy Elefánti Jáklin József 1781. március 3-án Nagyszombatban „mintegy” hetvenéves korában halt meg, azaz 1711 körül született. A haláláról a Magyar Hírmondóban olvasható nekrológ összegzi életét. Eszerint a nagyszombati törvényszéken húsz évig volt ítélőbíró. Korábban Moson vármegyében volt aljegyző, majd Győr vármegyében főjegyző. Több fordítást is készített. ${ }^{12}$ A főnemesi Elefánti Jáklin család Vas megyéből települt át a 17. században Észak-Magyarországra, s egyik ága köznemesi sorba süllyedt. ${ }^{13}$ A fordító Jáklin József valószínúleg ez utóbbi ághoz tartozott. ${ }^{14}$ A nekrológban említett fordításai közül jelenleg egyedül a Palingenius-adaptáció ismert. ${ }^{15}$

A fordítás négy fennmaradt példánya közül az Országos Széchényi Könyvtárban és az Egerben őrzött példányt vizsgáltam meg. Mindkettő másolat, a szöveg tiszta írásképén kívül ezt bizonyítja például, hogy a másolói figyelmetlenség miatt kimaradt részeket ugyanazon kéz pótolta a lapszélen. ${ }^{16}$ A fólió alakú, félbőrbe kötött kéziratpéldányok közül az

\footnotetext{
10 Valószínűleg azért, mert egy egyházi indexen lévő munka fordítását forgalmazni sem lehetett.

11 A pozsonyi példányt Stoll Béla a 18-19. századi kéziratok között a 104. számon írta le. STOLL (2002: 16). A Stoll-féle példányról először Klaniczay Tibor tudósított 1955-ben: KLANICZAY (1955: 436). Egy második másolatot eredeti kéziratként katalogizáltak az Országos Széchényi Könyvtárban (Kézirattár Fol. Hung. 160); ez a példány Széchényi Ferencé volt. Az általam ismert harmadik másolatot az Egri Főegyházmegyei Könyvtár őrzi a Gg. IV. 13 jelzeten. Ez a példány Barta (Bartha) István (1719-1785) egri kanonok, novi címzetes püspöké volt, aki 1782. augusztus 3-án ajándékozta a könyvtárnak. Elfelejthetetlen (1819: 31-32). A pécsi Egyetemi Könyvtár példányára Klaniczay Tibor hívta fel a figyelmet. KLANICZAY (1955: 436). Ez a példány Schmelczer-Pohánka Éva felvilágosítása szerint jelenleg nem található.

12 [Nekrológ] 1781.

${ }^{13}$ CSízi (2012: 112-114).

14 Vö. SZLUHA (2003: 527-529).

15 SZINNYEI (1981: 301-302).

16 Ilyen például az Országos Széchényi Könyvtár példányában a gépi számozású 171r lapon a 264-265. versszak.
} 
egri 269, a budapesti 290 levél terjedelmü. A terjedelmi különbség oka az, hogy az egri példány végére nem másolták be a mutatót. A fordítás teljes címe a következő: Palingen Marczell igen bölcs Tsillagos Poetanak Vagy-is Verss szerzőnek Zodiacus, azaz Égi abroncsos Planetabeli egygyezö Élete. Az Embereknek igen jóra intézó Életirül Igyekezeti és Szokásirúl XII. Könyvbül álló Kohollót Verss, mely sokaig es ohajtva váratot. Deák nyelven, most pedig üdö közbe forgó mulatság kedvéért magyar nyelv és versekre fordéttatott Elefánti Jáklin Jósef Fölséges Koronás Királyné Maria Theresia Aszszonyunknak Dunán innéd [!] való Districtualis Törvényes Táblának Assessora altal. Nagyszombatban 1771. Esztendöben.

Jáklin ebben a némileg körülményes formában törekedett a latin cím visszaadására, magyarázatára és kiegészítésére. A „kohollót verss” kifejezés minden valószínűség szerint - a latin confictiónak megfelelően - az eredetitől való nyelvi eltérésekre kívánta felhívni a figyelmet, arra, hogy a fordítás nem szó szerinti. Az adaptáció bizonyos mértékü „önkényességét" jelzi az is, hogy Jáklin - valószínüleg saját ízlését követve - elhagyta a keretszövegek átültetését - köztük Palingenius argumentumát -, s ehelyett egy, a müvet sajátosan átértelmező, magát a szerzőtől némileg elhatároló bevezető verset írt, Intés az olvasó keresztény emberhez címmel. Jáklin e versezettel föltehetően el akarta távolítani munkáját az indexen lévő eredetitől, így teremtve lehetőséget a fordítás kinyomtatására. Az Intés egyben ráirányítja a figyelmet a mü és a fordítás kapcsolatára. A rímes tizenkettesekből álló, négy soros strófákra tagolt bevezető egyrészt kritikával illeti a Zodiacus vitae tartalmát, s érezhető távolságot tart attól. Másrészt a hangvétel és a szóhasználat jelzi, hogy a fordító katolikus, s nem ért egyet a lefordított mü minden részletével; elhatárolódik attól, azaz a fordítás egyúttal értelmezés és olvasat.

A kérdésre, vajon melyik latin kiadásból fordított Jáklin, nem adható pontos válasz, mivel a fordító könyvtárának katalógusa nem ismert, a könyvek előtt található prózai összegzések a Zodiacus vitae számos kiadásában megjelentek, $\mathrm{s}$ több kiadás tartalmaz mutatót is. ${ }^{17}$ Mivel a Jáklin által használt kiadást nem lehet meghatározni, a fordítást a gondosan sajtó alá rendezett, Magyarországon is ismert és kedvelt 1722. évi

17 Több olyan kiadás is készült, így például a bázeli 1621. évi (König), amelyben van index, de nincsenek összegzések. 
rotterdami kiadással és a Jacques Chomarat által készített kritikai kiadás szövegével vetettem össze. A terjengős, gyakran keresett szóhasználattal élő fordítás nyelvileg körülményesnek és nehézkesnek tűnik a gördülékeny, elegáns latinságú eredetihez viszonyítva. Ugyanakkor érzékelhető a törekvés a tartalom érzékletes, minél szórakoztatóbb átültetésére. A fordítás olyan megoldásokat is tartalmaz, amelyek révén nyilvánvaló a távolság a latin eredetitől. Mindez ráirányítja a figyelmet Jáklin törekvésére, hogy a magyar szöveg lehetőleg igazodjon a korban közérthetőnek tartott és használt nyelvhez, valamint a katolikus olvasók ízléséhez. A fordítást jellemzi a kihagyásos módszerrel párosuló bőbeszédűség, ami az adaptációt eltávolítja az eredetitôl. A jobbára magyarázkodó fordításban csaknem teljesen elvész Palingenius szövegének „feszessége”, világossága és nyelvi-stiláris eszközökkel biztosított erőteljes kifejezésmódja. A közérthetőséget célzó, terjengős magyar szövegből kimaradt több, az eredeti értelemhez „,kulcsot” adó részlet. E jellegzetességek miatt a fordítás az eredetinél jóval alacsonyabb intellektuális szinten valósul meg. A nyelvi-gondolati gazdagság egy része elsikkad; az értelmezések megtöbbszörözése helyett a szöveg egysíkúvá válik.

Ma eldönthetetlen, hogy a csupán töredékesen fennmaradt, minden valószínűség szerint a 19. század első felében készült másik magyar fordításnak mekkora lehetett a teljes terjedelme. ${ }^{18}$ Ezt az unitárius Ifjabb Pettényi Gyöngyössy János (1783-1842 után?) készítette 1820 körül, iskolai használatra. Az utóbbira utal, hogy a kézirat a latin-magyar szöveget párhuzamosan, bal oldalon (a verzókon) a latin eredetit, jobb oldalon (a rektókon) a magyar változatot tartalmazza. A fennmaradt töredék jelenleg egyetlen füzetből áll, ${ }^{19}$ melynek hiányzik az eleje és a vége. A füzet a Zodiacus vitae első két könyvét tartalmazza. A Jáklin-féle másolati példányokhoz hasonlóan ez a kézirat sem tekinthető autográfnak. Ezt bizonyítja egyrészt, hogy a másoló nem vette észre a szöveghiányokat, ${ }^{20}$

\footnotetext{
18 Őrzőkönyvtár és jelzet: Biblioteca Academiei Române - Filiala Cluj-Napoca Ms U1163. 19 A nyomtatott katalógus sajátos módon, minden indoklás nélkül 1805-1810 körülre datálja a kéziratot, elhallgatja kétnyelvüségét, és Palingenius helyett az előzékvers szerzőjét, Thomas Scauranus-t teszi meg szerzőnek. LAKÓ (1997: 233).

${ }^{20}$ Az 59. lapon a magyar szöveg 178-199. sora, a 60. lapon a latin szöveg 200-224. sora hiányzik.
} 
amire a fólió-számozás készítője sem figyelt fel. Másrészt a latin szövegben gyakoriak a tipikus másolói hibák.

A fordító személyéről - Jáklin Józsefhez hasonlóan - nagyon kevés adat áll rendelkezésre. Az adatok elkülönítése elsősorban azért nehéz, mert Erdélyben egykorúan több „Gyöngyössi János” élt és alkotott. ${ }^{21}$ Ifjabb Pettényi Gyöngyössy János 1783-ban született id. Gyöngyössy János negyedik gyermekeként. Neve 1799-ben szerepel a Nagyenyedi Kollégium diáknévsorában. 1816-1820 között Budán, 1820-ban Pesten tartózkodott, Árpád-eposza 1824-ben jelent meg Nagykárolyban. ${ }^{22}$ Több omniáriuma maradt fenn az 1839-1842 közötti évekből, melyeket a kolozsvári Akadémiai Könyvtár unitárius gyưjteménye őriz (Ms U636/AIIII, B, C). ${ }^{23}$

A fordítást tartalmazó füzet címlapján a Gyöngyviragak Violak és Nefelejtsek Első bokréta. Iső Füzet szöveg olvasható. Oktatásra, kiadási szándékkal készült, jegyzetekkel, valamint egy rézmetszettel tervezték ellátni. Gyöngyössy igyekezett az eredetivel egyező időmértékben fordítani. A „Szabadon Magyarra fordítván” megjegyzés a szóhasználatra, a magyar szavak bizonyos keresettségére céloz. Gyöngyössy szöveghü fordításra törekedett, ugyanakkor ezt a célt egyéni módon valósította meg. Jáklinhoz hasonlóan Gyöngyössynél sem dönthető el, hogy melyik kiadás alapján dolgozott. Az iskolásan „felszerelt” Gyöngyössy-féle latin szöveg magyar fordítása is „iskolás”-an hangzik. Ezt a hatást éri el a fordító egyrészt az eredetihez való szoros ragaszkodással, másrészt a latin szöveg értelmezéseként betoldott, az érthetőséget elősegíteni kívánó, de valójában azt megzavaró részletekkel. Ilyen sajátosság nem fedezhető fel Jáklin fordításában, aki az idézett sorokat úgy magyarította, hogy alig lehet ráismerni az eredetire.

Jáklin és Gyöngyössy fordítása egyéni tudásukhoz igazodó interpretációként, egyfajta sajátos confictióként, „,szabad” fordításként értékelhető. A fordítói értelmezés összekapcsolódott a magyar nyelv „hétközna-

\footnotetext{
${ }^{21}$ SZINNYEI József (1896: 63-64) például a vele nem azonos Gyöngyössi Jánossal, királyi helytartótanácsi számvevő hivatalnokkal, 1805-ben nagyenyedi tógás diákkal azonosította a kézirat szerzőjét. Egy másik ifjabb Gyöngyössy János 1741-1818 között élt.

22 Utóbbi munkájáról ld. MARGÓCSY (2015: 53-56).

${ }^{23} \operatorname{KESZEG}(2011:$ 173, 194-197, 252).
} 
pias", kevéssé választékos használatával. A két fordító teljesítménye a korban elvárt mérce alatt marad, irodalmi szempontból kevéssé invenciózus, esztétikai minőségük gyenge. Egyik fordítás sem mérhető össze a 18. század és a 18-19. század fordulójának jelentős fordítói életmúveivel, mint például Mikesé, Faludié vagy Kazinczyé. Ugyanakkor - egymástól függetlenül - ők ismerték fel elsőként a teljes „magyar Palingenius” hiányát, és igyekeztek pótolni azt. Egyik fordítást sem kísérik elméleti reflexiók. Jáklin szórakozásból fordított, és egy másokat szórakoztatni vágyó interpretációt készített. Gyöngyössy a latin nyelv oktatási "segédanyagaként” viszonyult a Zodiacus vitae-hez, s a tanuláshoztanításhoz hasznosnak vélt „minta-fordítást” kívánt készíteni. A megvalósított nyelvi-stilisztikai teljesítmény és értelmezői reflexió szegényes; mindkettőjük szóalkotási tehetsége, fordítói invenciója erősen behatárolt. $^{24}$

\section{A Vergilius, Horatius és Ovidius müveiből származó részletek adaptációja a Zodiacus vitae fordításaiban}

A három római költőtől eredeztethető vagy rájuk utaló részletek összegyüjtésekor a Zodiacus vitae kritikai kiadásának jegyzeteiből indultam ki. ${ }^{25}$ Megkerestem a Palingeniusnál fellelhető, Vergiliusra, Horatiusra és Ovidiusra utaló részleteket, sorokat és motívumokat, majd ezekből kiindulva megvizsgáltam az utalások fordításokban elfoglalt helyét, funkcióját és lehetséges értelmezési tartományát.

Az antik költők jelenléte a Zodiacus vitae-ben számos különféle retorikai-stilisztikai pozícióban érhető tetten. Legritkább az, amikor egy

\footnotetext{
${ }^{24}$ A két magyar kéziratos „Palingenius”-on kívül készült egy nyomtatásban megjelent német próza-fordítás is a Zodiacus vitae egy rövid részletéből. Ennek jelenleg ismert egyetlen példánya a Tiszántúli Református Egyházkerület Nagykönyvtárának egyik kolligátum kötetében található, két folio terjedelemben. Debrecen, Tiszántúli Református Egyházkerület Nagykönyvtára, A 1501. A nyomtatványt a retrospektív magyar nemzeti bibliográfiában még nem regisztrálták. A nyolcadrétű aprónyomtatvány először latinul, majd németül közli ugyanazt a szövegrészt. Marcelli Palingenii (1822). A latin-német nyomtatvány a Zodiacus vitae kilencedik könyvéből (Sagittarius) tartalmazza a 38-78. sorokat. A német nyelvü részletet összevetettem az 1822 előtti német fordításokkal (Johann Spreng, 1564; Franz Schisling, 1785; Johann Joseph Pracht, 18031815), de semmiféle nyelvi egyezést nem találtam.

${ }^{25}$ CHOMARAT (1996).
} 
csaknem teljes antik verssor azonosítható. Ezzel szemben viszonylag gyakori a rögzültnek tekinthető kifejezések átvétele vagy ilyen részletek mozaikszerü összerakása. Gazdagnak mondható az irodalmi allúziók többrétü, szinte folyamatos előfordulása és az utalások a jellegzetes, jól felismerhető irodalmi képekre, fordulatokra. Néhány részlet értelmileg idéz fel az antik költészetből eredeztethető helyzeteket, állapotokat vagy tényeket. Elöfordulnak olyan történetekre vonatkozó utalások is, amelyek egy-egy konkrét szerzőre irányítják a figyelmet. Végül elkülöníthető néhány, egyszerre több szerzőt felidéző történet. Mindezeket a változatokat kiválasztott példák ${ }^{26}$ segítségével összevetem a magyar fordításokkal, és igyekszem levonni a recepcióra vonatkozó következtetéseket.

Egy csaknem teljes antik verssor kihagyása, illetóleg átvétele.

A Zodiacus vitae II, 480 (Minoisque urnam spernit, Stygiosque furores) egy Vergilius-sort $(A .6,432)$ idéz: quaesitor Minos urnam movet; ille silentium (Minós itél itt és Urnát rázva behívja) ${ }^{27}$. A halála után a holtak egyik bírájára, Kréta egykori királyára, Zeusz és Európé fiára, Minószra vonatkozó sor Jáklin fordításából egyszerüen kimaradt. Gyöngyössynél másféle számozás alatt (II, Taurus, 442-443) csaknem tükörfordításban olvasható e Palingenius-sor: [...] és megveti még a' Halált is, / Mínószi Úrnáját, 's a' Stikszet számba se vévén; Ez a megoldás, úgy tünik fel, alkalmasnak bizonyult az eredeti vergiliusi sor átadására, közvetítésére.

Rögzült kifejezések.

Ezek a kifejezések két vagy több egymáshoz kapcsolt szóból állnak, s az antik mintát követő sorrendben, vagy ahhoz hasonlóan azt idézik emlékezetbe. Az első példa a Zodiacus vitae I, 41 (Adsis, et placido vultu dignare poëtam) sora, mely a vergiliusi adsis o placidusque iuves et sidera caelo / dextra feras (A. 4, 578-579, Oltalmazz kegyesen hát bennünket s a szerencse / csillagait hozzánk igazítsd) részleges idézésével készült. Míg Gyöngyössy fordítása (I, Aries, 61: mégis azért kegyesen méltóztassál letekinteni rám)

\footnotetext{
${ }^{26}$ Az egy-egy típushoz tartozó példák számát maximum háromban limitáltam.

${ }^{27}$ A Vergilius-idézeteket LAKATOS István (1967) fordításában idézem.
} 
közvetíteni látszik Vergiliust Palingenius révén, Jáklin megoldása ettől némileg távolabb áll: Tekénts ream szegényre nagy Kegyességeddel..$^{28}$

Az ovidiusi concha Sidonide kifejezés a Metamorphoses Pygmalion történetéből származik (Concolat hanc stratis concha Sidonide tinctis - Sidoni biborral készült kerevetre teríti, ${ }^{29}$ Met. 10, 267), a szókapcsolatot Palingenius a Sunt o sunt multi, Sidonia concha superbos (ZV I,164) sorban használta. Míg Jáklin kihagyta, Gyöngyössy körülményesen, az ovidiusi eredetire kevéssé emlékeztetően fordította le kínos pontossággal, magyarázva (Bársonyak, és seljem Ruha) a palingeniusi sort Ó bizonyára sokan vagynak, kiket a' Csigavérrel / festett Bársonyak, és seljem Ruha, pöffedezőkké / tésznek [...] (I, Aries, 164-166).

Vergilius rumpe moras kifejezését (heia age, rumpe moras. varium et mutabile semper / femina [...] - Rajta tehát, ne habozz. Amilyen hóbortos az asszony, / éppolyan ingatag is [...] A. 4, 569-570) Palingenius a Perge igitur, iam rumpe moras altumque petamus (ZV II, 21) sorban használta fel. Ezt Jáklin nem fordította le, Gyöngyössy pedig az [...] azért indúlj, a' magoss Tengerre kisszálljunk. (II, Taurus, 21) sorral adta vissza. Sajátos, hogy Gyöngyössy éppen a rumpe moras kollokációról mondott le, ugyanakkor beemelte a Tengerre kifejezést, ezzel érzékeltetve, hogy felismerte, Palingenius Vergiliust idézi: azt a jelenetet, amikor Mercurius a Didót elhagyni készülő, de még habozó Aeneast ösztönzi elhajózásra.

Rögzült kifejezések mozaikszerü összerakása vagy elhagyása.

Zodiacus vitae II, 27-28. sorai: Ex his tantum homini quid sit cognoscere uerum, / Quidue decens et posse loqui, concessit; at ore, melyből egy szókapcsolat minden valószínüség szerint Horatius, Epistulae 1, 1, 11-ből ered quid uerum atque decens, curo et rogo et omnis in hoc sum; (teljes erômból azt kutatom, mi a jó, mi az illó). ${ }^{30}$ A quid verum decens és a vonatkozó Palingenius-sor Jáklinnál nem található meg. Gyöngyössy itt is pedagogikus célzattal igyekezett pontosan lefordítani a Zodiacus vitae e részletét ([...] ezek közzül csak az egy Embernek adá meg / a' magos Esmeretet, hogy megtud-

${ }^{28}$ A Jáklin-féle másolatok közül az egri Gg IV. 13 jelzetü példány szövegét idézem. Itt: Aries I, 14. versszak.

29 A Metamorphosest DEVECSERI Gábor (1975) fordításában idézem.

30 BEDE Anna (1989) fordítása. 
hassa, mi Jó? mi / Illó, vagy Roszsz és Illetlen, ez eggynek adott olj / égi Tehetséget, hogy gondoljon, 's kifejezze Gondolatit hangos szóval [...] II, Taurus, 26-29), némileg eltávolodva a horatiusi kifejezéstől.

Egy másik példa a bőségszaru (cornu copiae). Horatius [...] Hic tibi copia / manabit ad plenum benigno / ruris honorum opulenta cornu (Carmina 1, 17, 13-15, Ím a bőség kürtje kiömlik eléd, ha eljössz) ${ }^{31}$ sorát Palingenius az Effundat cornu quicquid vis Copia, numquid (ZV 2,195) sorban használta fel. Jáklinnál nincs nyoma, s az antik utalás Gyöngyössynél is elvész a 's bár Bővségbe' legyen, keveset fog venni belőlle, fordításban (II, Taurus, 195).

Irodalmi allúziók

Az utalások, rejtett célzások és másként való megnevezések sora gazdag, előfordulásuk sokrétű. Elsősorban az eredeti szöveg és a felhasználó közös élményére támaszkodik, értelmezhetôsége feltételezi a közös irodalmi hagyomány ismeretét, jelen esetben a magas minőségü antik előzmény használatát Palingeniusnál, majd ennek tudatos áttételét a fordítók invenciója által.

A példaként választott első allúzió a közismert Horatius-sor, Odi profanum vulgus et arceo (Carmina 3, 1, 1, megvetem és távol tartom magamtól az egyszerú népet). ${ }^{32}$ Palingeniusnál a Lux tua monstret iter, per quod penetralia templi / Ingrediar tui, et me Subtrahe vulgo (ZV 1, 12-13) sorpár idézi fel, melyet Gyöngyössy Horatiust felismerő és számításba vevő megoldással, három sorban adott vissza: Fényelj Te, Világosság' Súgárival, Útam elébe, / tiszteltt Templomodat, hogy meglelvén, bemehessek / abba, 's a' Köznéptől távol rejtezve lehessek (I, Aries, 11-14).

A szállóigeként jól ismert sic itur ad astra Vergiliusnál macte nova virtute, puer, sic itur ad astra (A. 9, 641, élj az új lehetôséggel gyermek, így jutsz fel a csillagokig!), Palingeniusnál Sidera, spectabitque altos mens enthea divos (ZV 1, 20). A csupán Gyöngyössytől lefordított sor magyarul - Csillagihoz, 's Elmém a' Nagy Isteniek' Seregökben / mulatoz [...] (I, Aries, 20-21) bár pontosan követi Palingeniust, távolra kerül Vergilius eredeti kifejezésétől.

\footnotetext{
31 Radnóti Miklós fordítása. TRENCSÉNYI-WALDAPFEL (1940: 165).

32 Irodalmi fordítása: „Szentségtelen nép, félre! gyülöl szivem” (Székács József). TRENCSÉNYI-WALDAPFEL (1940: 85).
} 
A harmadik példa egy Horatius-allúzió, eredetije a cum segetes occat tibi mox frumenta daturus (Epistulae 2, 2, 161), ${ }^{33}$ amit Palingeniusnál az Occandae, fabricanda domus, vitesque putandae (ZV 2, 124) sor idéz fel. Utóbbi, eltávolodva mindkét változattól, Jáklinnál Fóldemet azután szántom és kapálom / Szép rossal bévetem, jól be boronálom, (Taurus II, 42. versszak), Gyöngyössynél [...] kaszálni; / mettzeni kell most a' szöllöt; építenem is kell / egy újj Házat. Pénzt kell bevennem [...] (II, Taurus 124).

A példák rávilágítanak az allúziók eltérő módszerü átültetésére, melynek során a magyar változatok eltérő távolságba kerültek az antik forrásszövegektől.

Utalások irodalmi képekre, bevett fordulatokra.

E csoportba olyan részleteket soroltam, melyek ugyanazt az eseményt vagy dolgot idézik fel, esetenként frázisszerüen. A tavasz beköszöntének klasszikus megfogalmazása Horatiusnál a közismert Solvitur acris hiems grata vice veris et Favoni (Carmina 1, 4, 1, Enged a tél a tavasz meg a langy szelek édes ostromának). ${ }^{34}$ Palingeniusnál a tavasz leírása hasonló nyelvi elemekből építkezik: Unda silet, Zephyrus redit expectatus ab orbe (ZV 2,12). Ez a kép megjelenik Jáklin fordításában (Most midőn a' Tenger immár meg Csendesölt / Gyönge Zefyrus szél édesdeden süvölt Taurus II, 4. versszak), ami nála éppúgy a sikerültebb, antik elemeket átörökítő sorok közé tartozik, mint Gyöngyössy megoldása (Csendesek a' Habak, a' Zefirusz megjött az Enyészet' / Széleiről; [...] II, Taurus, 12-13). A „siker” oka mindkét esetben a fordítók iskolás müveltségében kereshető, ahonnan a megtanult antik évszak-frázisok nehézség nélkül átkerültek a fordításba. ${ }^{35}$

Egy másik kedvelt kép a napfelkelte. Palingenius (Quaerere, qua Titan populos despectat Eoos, ZV 2,49) vergiliusi örökséget használt fel (extulerit Titan radiisque retexerit orbem - ha felébred Titan és megujulva megint beragyogja világunk, A. 4,119). Jáklin ezt kihagyta, Gyöngyössy a mind

\footnotetext{
33 Irodalmi fordítása: „Ha nagyot és kicsinyt vág Orcus' kaszája, / kit meg nem kérlelhet minden kincs' bányája?" KIS (1833: 432).

34 Szabó Lőrinc fordítása. TRENCSÉNYI-WALDAPFEL (1940: 133).

35 Vö. KNAPP (2014).
} 
oda, hól Títán a' Kelet' Népére kipillant, (II, Taurus, 49), kissé körülményes sorban fordította le, az antik forrás valószínüsíthető tudatában.

$\mathrm{Az}$ aranyat hordozó folyó képe szintén Vergiliustól (exercentque viri Pactolusque inrigat auro. - szánt a paraszt, s aranyat dob Pactólus ki a partra, A. 10,142) származhatott át a Zodiacus vitae-be (Atque auri tantum quantum vel Lydius amnis, ZV 2, 74). ${ }^{36}$ Gyöngyössy némileg körülményesen, egy későbbi sorral összevonva fordította le, érzékeltetve az antik előkép ismeretét: [...] 's az Aranynak / olj Sokasága, minőt ama' gazdag Lidiusz, és a / tündöklő Tágúsz Foljók, Tengerbe kiöntnek; (II, Taurus, 73-75).

Egy-egy részlet értelemszerüen idéz fel az antik költészetból eredeztethető helyzetet, állapotot vagy tényt.

Ilyen például az ember törékenységéről szóló részlet, melyet Palingenius (ZV 2, 468-470) Ovidiust követve (Met. 1, 80-83) verselt meg, majd Gyöngyössy hasonló értelemben, bár a sorokat másként számozva adott vissza a [...] minthogy törékeny Anyagból / formáltatva vagyunk [...] (II, Taurus, 431-432) kezdettel. Egy másik példa a természetben végbemenő folyamatos változásra vonatkozik, ami szintén gyakori, a régi magyar költészetből is jól ismert toposz. ${ }^{37}$ Erről Palingenius (ZV 3, 159-169) Ovidius ismeretében (Met. 15, 259-283) verselt. Jáklin valószínúleg az utóbbi ismeretében fordított úgy, hogy az általa valószínúleg tanulmányai során elsajátított szólamokhoz igazodott: Üdövel az hegyek magokba elmulnak / Valamint a legyek oly könnyen el húlnak. / A' világ dolgai fenékkel fordúlnak. / Jövendökrül soha többé nem búsulnak. (Gemini III, 83. versszak).

Utalások egész történetekre.

Több antik történetre vonatkozó utalás sejtet ovidiusi előzményt. Ilyen például Dédalusz és Ikarosz említése (ZV 1,114 - Met. 8,183-235) vagy Midász király története (ZV 2,185-191 - Met. 11,85-193). Ízelítőként az utóbbi történet Jáklin-féle magyar átültetéséből idézek néhány sort: $M i$ -

\footnotetext{
36 A Pactolus folyó Lydiában fakadt. Az antik irodalomban többen megörökítették, hogy aranyat hordozott, mosott ki, így például Vergiliuson kívül Hérodotosz 5,101; Sztrabón, Geógraphika 13, 625; Horatius, Epodes 15, 20; Ovidius, Metamorphoses 11, 87.

${ }^{37}$ Vö. pl. Balassi Bálint, Negyvenhetedik. „Idővel paloták, házak, erős várak, városok elromolnak, / Nagy erő, vasztagság, sok kincs, nagy gazdagság idővel mind elmúlnak, / Tavaszi szép rózsák, liliom, violák idővel mind elhullnak".
} 
das is egykoron aztat óhajtotta / hogy mind arany lenne valamit meglátna / két szemének fénnyét akkor tapasztalta / midőn koplalását szamár füle látta (Taurus II, 67. versszak). E történetek antik irodalmi feldolgozásai gyakoriak, a fenti két esetben a szóhasználat miatt mindenekelőtt Ovidius ismerete valószínüsíthető.

Célzás több szerzőre.

A Zodiacus vitae bővelkedik olyan verssorokban is, amelyeknél több antik szerző egyidejü és egyenértékű ismeretére lehet gondolni. Ilyen például a si vel Scylla vorax, dubii vel saxa Capharei sor (ZV 2,118), amely egyaránt felidézi Vergiliust ([...] Minervae / sidus et Eubicae cautes ultorque Cahpereus - Minerva / zord csillagzata s Eubeán ama szirt, a Caphéreus A. 11,259-260) és Ovidiust (perpetimur Danai cumulumque Capherea cladis Met. 14,472 - törnek / ránk danaókra, s a legszörnyebb: Caphareus veszedelme Met. 14,471-472). Jáklinnál a két különböző tengeri veszély, a tengeri szörny Scylla és a veszélyes Caphareus szirt összevonva, mint „kőszikla” jelenik meg, így nála az antik utalás teljesen eltünik: Vagy is Kôsziklába hajom meg ütkőzik / ne talán fenékig ôszve tőrődözik (Taurus II, 39. versszak). Gyöngyössy azonban itt is igyekezett pontosan fordítani ([...] vagy $a^{\prime}$ torkos Scilla, akár a' / kétséges veszedelmü Kafáreusz iszszonyu Hegynek / Köszikláji, [...] II, Taurus, 118-120), s a szöveg jelzi, hogy a fordító valószínüleg mindkét antik helyet ismerte.

\section{Összegzés}

A néhány példa egyrészt bemutatja a három római költő sorainak „átszármazását" a Zodiacus vitae-be, másrészt jelzi a sorok hatását és további átalakulását az eposz két magyar fordításában. A másodlagos recepció elsősorban a szövegszerü, iskolai oktatásra szánt Gyöngyössyfordításban vizsgálható és követhető nyomon viszonylag folyamatosan. A kettős transzformáció során a bemutatott részletek többsége kisebbnagyobb mértékben eltávolodott az eredetitől. A példák arra is felhívják a figyelmet, hogy a hivatkozás nélküli, antik eredetü sorok egy része a magyar fordításban is felismerhető maradt.

Ismeretes, hogy Vergilius, Horatius és Ovidius 17-18. századi recepciójának egyik legjelentősebb színtere az iskolai oktatás volt. Nem tekinthető véletlennek, hogy a Zodiacus vitae magyarországi befogadás- 
története szintén e két évszázadban tekinthető a legintenzívebbnek. Elsősorban ez a körülmény tette lehetővé utóéletük vizsgálatát a Palingenius-mű másodlagos recepciója keretében.

\section{Felhasznált irodalom}

BEDE 1989

DE BUJANDA 1990

CHOMARAT 1996

CSÍZI 2012

DEVECSERI 1975

Elfelejthetetlen 1819

Index 1764

Index 1862

KELLER 1974

KESZEG 2011

KIS 1833

KLANICZAY 1955

KNAPP 2014

KÜHLMANN 2016

LAKATOS 1967

LAKÓ 1997
BEDE A. (ford.) Horatius összes müvei, Budapest, 1989.

J. M. De BujANDA (ed.), Index de Rome 1557, 1559, 1564: Les premiers index romains et l'index du Concile de Trente, Sherbrooke, 1990.

J. Chomarat (ed.), Palingène (Pier Angelo Manzolli dit Marzello Palingenio Stellato) Le zodiaque de la vie (Zodiacus vitae) XII livres, Texte latin établi, traduit et annoté, Genève, 1996.

Csízi I., A királyi Magyarország főnemesi családjainak címerváltozatai a 16-17. században, Doktori disszertáció, ELTE BTK, Budapest, 2012.

DeVecseri G. (ford.), Publius Ovidius Naso, Átváltozások, Budapest, 1975.

Elfelejthetetlen emlékezetü Egri Püspök Galanthai Gróf Eszterházy Károlynak jeles élete [...] az általa szerzett, utána pedig nevekedett, megyebéli Könyvgyüjteménynek leírása In: Tudományos Gyüjtemény 3 (1819) V. kötet, 3-32.

Index librorum prohibitorum, Romae, 1764.

Index librorum prohibitorum, Neapoli, 1862.

L. KELLER, Palingène - Ronsard - Du Bartas. Trois études sur la poésie cosmologique de la renaissance, Bern, 1974, 9-60.

KeszeG A., Gyöngyössi János. Szövegek és kontextusok, Budapest, 2011.

KIS J. (ford.), Horatius' levelei, Pest, 1833.

KLANICZAY T., Magyar nyelvü verses kéziratok Csehszlovákia könyvtáraiban és levéltáraiban, in: A MTA Nyelv- és Irodalomtudományi Osztályának Közleményei 7 (1955), 429-442.

KNAPP É., „Volucris rota, vertitur anni”, Zrínyi Miklós, Listius László és Esterházy Pál szerencse- és évszakverseinek poétikatörténeti hátteréhez, in: Irodalomtörténeti Közlemények 118 (2014) 3-30.

W. KüHLManN, Wissen als Poesie, Berlin - Boston, 2016.

LAKATOS I. (ford.), Vergilius összes müvei, Budapest, 1967.

E. LAKÓ, The Manuscripts of the Unitarian College of Cluj/Kolozsvár in the Library of the Academy in Cluj-Napoca, I, Catalogue, Szeged, 1997.

Marcelli Palingenii 1822 Marcelli Palingenii oratio supplex ad ens supremum - Gebeth des Marcell Palingen an das höchste Wesen, Leutschau, 1822.

MARGÓCSY 2015 MARGÓCSY I., Tündér a honfoglalásban. A regemüfaj különös változata in: Tempevölgy 7 (2015) 1. sz., 50-59. 
[Nekrológ] 1781 [Nekrológ] In: Magyar Hírmondó 1781, 21. szám, 162-163.

Palumbo 2007 M. Palumbo, Manzoli, Pier Angelo, in: M. Caravale (dir.), Dizionario Biografico degli Italiani, vol. 69 Mangiabotti Marconi, Roma, 2007, 294-298.

SCALIGER 1607 J. C. SCALIGER, Poetices libri septem, [Heidelberg], 1607.

STOLL 2002 STOLL B., A magyar kéziratos énekeskönyvek és versgyüjtemények bibliográfiája (1542-1840), Budapest, 2002.

SZINNYEI 1896 SZINNYEI J., Magyar írók élete és munkái, IV. kötet, Budapest, 1896.

SZINNYEI 1981 SZINNYEI J., Magyar irók élete és munkái, V. kötet, hasonmás kiadás, Budapest, 1981.

SzluHA 2003 SzluHA M.., Nyitra vármegye nemes családjai, I. kötet, Budapest, 2003.

Telle 2013 J. Telle, Alchemie und Poesie. Deutsche Alchemikerdichtungen des 15. bis 17. Jahrhunderts, Bd. I., Berlin - Boston, 2013, 503-508.

TRENCSÉNYI-WALDAPFEL 1940

TRENCSÉNYI-WALDAPFEL I. (összeáll.), Magyar Horatius, Budapest, 1940. 